\title{
The effect of age and level of dietary calcium intake on calcium metabolism in sheep
}

\author{
By G. D. BRAITHWAITE AND SH. RIAZUDDIN \\ National Institute for Research in Dairying, Shinfield, Reading $R G 2{ }_{9} A T$
}

(Received 28 September 1970-Accepted 2 February 1971)

\begin{abstract}
I. A combination of balance and isotope techniques has been used to study the effects of age and dietary calcium content on $\mathrm{Ca}$ metabolism in forty-two wether sheep.

2. The amount of $\mathrm{Ca}$ absorbed by young growing animals varied significantly with intake. The percentage of the dietary $\mathrm{Ca}$ absorbed, however, remained unchanged. In older animals the amount of $\mathrm{Ca}$ absorbed was not altered by changes in intake, but decreased slightly with age.

3. Retention of $\mathrm{Ca}$ was directly related to the amount of $\mathrm{Ca}$ absorbed and was independent of age or breed. Furthermore, nearly all the $\mathrm{Ca}$ absorbed above the minimum mean amount required for maintenance was retained.

4. Faecal endogenous loss of $\mathrm{Ca}$ also was related to the amount of $\mathrm{Ca}$ absorbed. Values for faecal endogenous $\mathrm{Ca}$ were much lower than those used in the calculation of dietary requirements by the Agricultural Research Council (1965).

5. Urinary $\mathrm{Ca}$ excretion was variable, and was not related to age or changes in dietary $\mathrm{Ca}$ intake.

6. Increased absorption of $\mathrm{Ca}$ in young growing animals was accompanied by a decreased rate of bone resorption, but the rate of bone accretion remained unchanged. Changes in dietary $\mathrm{Ca}$ in older animals had no effect on either of these two processes. Results indicate that bone resorption is the main pathway governing $\mathrm{Ca}$ homoeostasis. Both the rates of $\mathrm{Ca}$ accretion into bone and resorption from bone decreased with age.

7. Neither the rapidly exchangeable Ca pool (P) nor the slowly exchangeable bone pool (E) was altered by changes in dietary intake in young or mature animals. Both, however, decreased in size with age.

8. The size of the slowly exchangeable pool (E) was directly related to the rate of $\mathrm{Ca}$ accretion into bone.

9. The results were used to calculate dietary $\mathrm{Ca}$ requirements of sheep gaining weight at different rates, and these values have been compared with values recommended by the Agricultural Research Council ( 1965$)$.
\end{abstract}

The effect of age on calcium metabolism in ruminants in general and sheep in particular has received little attention and what few studies there are have tended to be confined to one particular aspect of metabolism. Ca requirements of sheep gaining weight at different rates have been calculated by the authors of The Nutrient Requirements of Farm Livestock (Agricultural Research Council, 1965). These authors emphasized, however, the lack of information available on the sheep.

The purpose of the work now presented was to study the effects of age and level of $\mathrm{Ca}$ intake on the various processes of $\mathrm{Ca}$ metabolism in the sheep and at the same time to obtain more information on its $\mathrm{Ca}$ requirements.

\section{EXPERIMENTAL}

Animals, housing and diet. Forty-two wethers of various breeds (Dorset Horn, Southdown and Suffolk $\times$ Half-bred) were used in these investigations. The effects of age and dietary $\mathrm{Ca}$ content on $\mathrm{Ca}$ metabolism were studied in growing (6-month-old) and in mature (16-month-old) wethers, with six animals of the same age and breed 
assigned to each of two diets differing in their Ca content. In addition, the effect of age was studied in 2-, 3-, 9- and 70-month-old wethers using three animals at 2 and 3 months and six at 9 and 70 months.

Table I. Composition and calcium content of the diet given daily to sheep 2, 6, 9, 16 and 70 months of age (3-month-old animals were given these dietary ingredients at $\mathrm{I} \cdot 5$ times these amounts)

\begin{tabular}{|c|c|c|c|}
\hline Ingredient & $\begin{array}{c}\text { Amount } \\
(\mathrm{g} / \mathrm{kg} \text { body-wt })\end{array}$ & $\begin{array}{l}\text { Ca content } \\
(\mathrm{mg} / \mathrm{g})\end{array}$ & $\begin{array}{c}\text { Total Ca } \\
(\mathrm{mg} / \mathrm{kg} \text { body-wt) }\end{array}$ \\
\hline Hay & 16 & $3 \cdot 28-4 \cdot 84$ & $52 \cdot 5-77 \cdot 4$ \\
\hline Barley & 4 & $0.4 I-I \cdot 00$ & $1 \cdot 6-4 \cdot 0$ \\
\hline Flaked maize & 2 & $0.01-0.07$ & $0.0-0.1$ \\
\hline Bran & I & $0.72-0.74$ & $0.7-0.7$ \\
\hline Linseed oil cake & 0.5 & $2.90-3.29$ & $I \cdot 5-I \cdot 6$ \\
\hline Mineral mixture & 0.3 & $184 \cdot 00-187.40$ & $55 \cdot 2-56 \cdot 2$ \\
\hline Vitamin mixture $\dagger$ & 0.028 & $3 \cdot 78-4 \cdot 41$ & $\begin{array}{c}0.1-0.1 \\
111.6-140.1\end{array}$ \\
\hline
\end{tabular}

* Super Mindif; Boots Pure Drug Co., Nottingham. [I6-month-old animals on a low Ca intake were not given the mineral mixture; 6 -month-old animals on a high $\mathrm{Ca}$ intake were given the mineral mixture at twice this amount (i.e. $0.6 \mathrm{~g} / \mathrm{kg}$ )].

$\uparrow$ Drivite; Boots Pure Drug Co., Nottingham. To supply 125 i.u. vitamin A and 3 r i.u. cholecalciferol/ kg body-wt.

Animals were placed in metabolism cages designed for the separate collection of urine and faeces at least I month before the start of an experiment and were fed on a diet of hay and concentrates. The amount of food given was calculated according to body-weight (Table $\mathrm{I}$ ) but, during the several years over which these investigations have proceeded, different batches of the various dietary constituents varied considerably in $\mathrm{Ca}$ content, resulting in different $\mathrm{Ca}$ intakes (see Table 3).

In experiments on ageing, 3 -month-old animals, which were in a very active state of growth, were given the dietary ingredients at $\mathrm{I} \cdot 5$ times the values shown in Table $\mathrm{I}$ and, in studies on the effect of $\mathrm{Ca}$ intake on Ca metabolism, dietary levels of $\mathrm{Ca}$ were changed by varying only the amount of mineral supplement added. Older animals (I 6 months of age) on the lower $\mathrm{Ca}$ intake were given no mineral supplement, whereas those on the higher intake were given $0.3 \mathrm{~g} / \mathrm{d}$ per $\mathrm{kg}$. Young animals ( 6 months of age), however, which are able to utilize much greater amounts of dietary $\mathrm{Ca}$, were given $0.3 \mathrm{~g} / \mathrm{kg}$ and $0.6 \mathrm{~g} / \mathrm{kg}$ on the lower and higher intakes respectively.

The concentrate mixture was completely consumed in all experiments and the daily hay consumption was determined by collecting and weighing the residues. Animals had free access to distilled water.

Experimental procedure. A known amount $(5 \mu \mathrm{Ci} / \mathrm{kg}$ body-weight) of an aqueous solution of ${ }^{45} \mathrm{CaCl}_{2}$ (Radiochemical Centre, Amersham, Bucks) was injected into the jugular vein, and samples of blood, urine and faeces were collected for a period of I week, as previously described (Braithwaite, Glascock \& Riazuddin, 1969). During this period $\mathrm{Ca}$ balance measurements were made.

Determination of $\mathrm{Ca}$ and measurement of radioactivity. Samples of blood, faeces and urine were prepared for analysis by the methods previously described (Braithwaite et al. 1969$)$. 
Calculation of values of the various processes of $\mathrm{Ca}$ metabolism. The method involves a combination of balance and radioactive techniques. The equation for the specific radioactivity-time curve of serum $\mathrm{Ca}$ was determined as described previously (Braithwaite et al. 1969). The faecal endogenous and urinary Ca losses were then calculated from the integral of the specific radioactivity-time curve and the total radioactivity excreted by each of these two pathways. The rate of $\mathrm{Ca}$ absorption was obtained from the equation:

$$
V_{a}=V_{i}+V_{f}-F,
$$

where $V_{a}$ is the rate of absorption of $\mathrm{Ca}$ from the intestine, $V_{i}$ the rate of ingestion of $\mathrm{Ca}, V_{f}$ the rate of excretion of $\mathrm{Ca}$ into the intestine (faecal endogenous $\mathrm{Ca}$ ) and $F$ the rate of loss of $\mathrm{Ca}$ in the faeces.

The method of Aubert \& Milhaud (1960), as described for the sheep (Braithwaite et al. 1969), was then used to calculate the rates of $\mathrm{Ca}$ accretion into bone $\left(V_{o}+\right)$ and of $\mathrm{Ca}$ resorption from bone $\left(V_{o}-\right)$, the sizes of the rapidly exchangeable $\mathrm{Ca}$ pool (P) and the slowly exchangeable $\mathrm{Ca}$ pool $(\mathrm{E})$ of bone.

Recently, the validity of these values (i.e. $V_{o}+, V_{o}-, \mathrm{P}$ and $\mathrm{E}$ ) obtained by kinetic analysis has been questioned (Neuman, Terepka, Canas \& Triffitt, I968; Burkinshaw, Marshall, Oxby, Spiers, Nordin \& Young, 1969). Burkinshaw et al. (1969) used a power series instead of using the sum of exponentials to describe the disappearance of radioactivity from the serum. They postulated a single continuously expanding exchangeable $\mathrm{Ca}$ pool and calculated mineralization rates which were somewhat lower than the values calculated by existing methods of kinetic analysis. We, however, have seen no advantage in changing our method of calculation and have continued to use in the present work the technique recommended by Aubert \& Milhaud (1960).

\section{RESULTS AND DISCUSSION}

Ca absorption (Table 2). There was a highly significant difference between the amount of $\mathrm{Ca}$ absorbed by two groups of young growing animals of the same age (6 months) and breed fed on diets differing only in the amount of $\mathrm{Ca}$ present, but the percentage of dietary $\mathrm{Ca}$ absorbed was about the same $(37-39 \%)$. These results suggest that the amount of $\mathrm{Ca}$ absorbed by these young animals was limited by the amount fed in the diet.

In older animals ( 16 months) where growth had ceased, there was no appreciable difference in the amount of $\mathrm{Ca}$ absorbed at the two levels of intake, resulting in a significant difference in the percentage absorption. In these animals, it was the capacity of the intestine to absorb $\mathrm{Ca}$ rather than the amount of $\mathrm{Ca}$ present in the diet that appeared to limit absorption and, unlike in young growing animals, increased absorption was not obtained simply by increasing the dietary intake. Intestinal control of absorption has also been suggested in ewes during pregnancy and lactation when insufficient $\mathrm{Ca}$ was absorbed to meet requirement in spite of a plentiful supply in the diet (Braithwaite et al. I969; Braithwaite, Glascock \& Riazuddin, 1970). Similarly, in work on cattle, Visek, Monroe, Swanson \& Comar (I953) have observed a decrease 
in the percentage absorption with increased dietary intake. In mature sheep, it is therefore the amount of $\mathrm{Ca}$ absorbed that is important and possibly as in most mammals (Bronner, 1964) 'the rate of extraction of $\mathrm{Ca}$ from the food is a reflexion of the state of $\mathrm{Ca}$ metabolism and not to any significant degree of the availability of the $\mathrm{Ca}$ in the food'. The term 'availability' is, therefore, not very meaningful from a physiological viewpoint in these older animals.

Table 2. Effect of level of calcium intake on Ca metabolism in young growing wethers (6 months of age and weighing 30-35 kg), and in mature wethers ( 6 months of age and weighing $5^{\circ-5} \mathrm{~kg}$ )

(Mean values with the standard error of the difference for six animals/group)

\begin{tabular}{|c|c|c|c|c|c|c|}
\hline & You & ng wethers & & $\mathrm{M}$ & ure wethe & \\
\hline & & & $\begin{array}{l}\text { Standard } \\
\text { error of } \\
\text { difference }\end{array}$ & & & $\begin{array}{l}\text { Standard } \\
\text { error of } \\
\text { difference }\end{array}$ \\
\hline & $\begin{array}{l}\text { Low Ca } \\
\text { intake }\end{array}$ & $\begin{array}{l}\text { High Ca } \\
\text { intake }\end{array}$ & $\begin{array}{l}\text { between } \\
\text { means }\end{array}$ & $\begin{array}{l}\text { Low Ca } \\
\text { intake }\end{array}$ & $\begin{array}{l}\text { High Ca } \\
\text { intake }\end{array}$ & $\begin{array}{l}\text { between } \\
\text { means }\end{array}$ \\
\hline $\begin{array}{l}\text { Rate of ingestion of } \mathrm{Ca}(\mathrm{mg} / \mathrm{d} \mathrm{kg} \\
\text { body-wt) }\end{array}$ & $130 \cdot I$ & $192 \cdot 6$ & $3 \cdot 7$ & $76 \cdot 4$ & $\mathrm{r} 49 \cdot 3$ & $5 \cdot 9$ \\
\hline $\begin{array}{l}\text { Rate of loss of } \mathrm{Ca} \text { in faeces* } \\
(\mathrm{mg} / \mathrm{d} \mathrm{kg} \mathrm{body-wt)}\end{array}$ & $100 \cdot 0$ & $140 \cdot 1$ & $5 \cdot 0$ & $75 \cdot 5$ & $146 \cdot 8$ & II I I \\
\hline $\begin{array}{l}\text { Rate of excretion of } \mathrm{Ca} \text { in urine } \\
(\mathrm{mg} / \mathrm{d} \mathrm{kg} \text { body-wt) }\end{array}$ & $3 \cdot 6$ & $4 \cdot 9$ & $1 \cdot 7$ & $5 \cdot 5$ & $7 \cdot 7$ & $2 \cdot 0$ \\
\hline $\begin{array}{l}\text { Rate of excretion of } \mathrm{Ca} \text { into intestine } \\
\text { (faecal endogenous } \mathrm{Ca})(\mathrm{mg} / \mathrm{d} \mathrm{kg} \\
\text { body-wt) }\end{array}$ & $18 \cdot 2$ & $22 \cdot 5$ & $I \cdot I$ & $16 \cdot 3$ & $18 \cdot 5$ & $x \cdot 6$ \\
\hline $\begin{array}{l}\text { Rate of absorption of Ca from } \\
\text { intestine }(\mathrm{mg} / \mathrm{d} \mathrm{kg} \text { body-wt) }\end{array}$ & $48 \cdot 3$ & $75 \cdot 0$ & $2 \cdot 0$ & $17 \cdot 2$ & $2 I \cdot 0$ & $2 \cdot 1$ \\
\hline $\mathrm{Ca}$ absorption as \% of $\mathrm{Ca}$ ingested & $37 \cdot 2$ & $39 \cdot 0$ & $1 \cdot 7$ & $22 \cdot 6$ & I3.9 & $3 \cdot 0$ \\
\hline Ca balance (mg/d kg body-wt) & $+26 \cdot 4$ & $+47 \cdot 6$ & $3 \cdot 4$ & $-4 \cdot 6$ & $-5 \cdot 3$ & $2 \cdot 8$ \\
\hline $\begin{array}{l}\text { Rate of accretion of } \mathrm{Ca} \text { into bone } \\
(\mathrm{mg} / \mathrm{d} \mathrm{kg} \text { body-wt) }\end{array}$ & $69 \cdot 2$ & $75 \cdot 6$ & 5.0 & $53 \cdot I$ & $52 \cdot 6$ & 4.2 \\
\hline $\begin{array}{l}\text { Rate of resorption of Ca from bone } \\
(\mathrm{mg} / \mathrm{d} \mathrm{kg} \text { body-wt) }\end{array}$ & $42 \cdot 8$ & $29 \cdot 6$ & $3 \cdot 7$ & $57 \cdot 6$ & $57 \cdot 9$ & $5 \cdot 1$ \\
\hline $\begin{array}{l}\text { Rapidly exchangeable pool of } \mathrm{Ca}(\mathrm{P}) \\
\text { (mg/kg body-wt) }\end{array}$ & $63 \cdot 3$ & $69 \cdot 3$ & 5.4 & $62 \cdot 0$ & $63 \cdot 2$ & $2 \cdot 7$ \\
\hline $\begin{array}{l}\text { Slowly exchangeable pool of } \mathrm{Ca} \text { in } \\
\text { bone (E) }(\mathrm{mg} / \mathrm{kg} \text { body-wt) }\end{array}$ & $\operatorname{II} 7.8$ & 122.9 & $\mathrm{I}_{4}{ }^{\circ} \mathrm{O}$ & 108.6 & $106 \cdot I$ & $9 \cdot 7$ \\
\hline
\end{tabular}

* Sum of faecal endogenous $\mathrm{Ca}$ and unabsorbed $\mathrm{Ca}$ lost/d.

Although the greatest effect of age on Ca absorption in the sheep occurred during the period of transition from a young actively growing animal to a mature adult, slight changes in absorption also occurred in the young and adult animals. In young growing animals the efficiency of absorption decreased from about $40 \%$ at $2-3$ months to $36 \%$ at 9 months (Table 3 ). In mature animals, however, where absorption itself was the limiting factor and was independent of dietary intake, the rate of absorption decreased slightly with age ('Table 3 ). Similar decreases in absorption with age have also been reported in cattle (Hansard, Comar \& Plumlee, 1954).

Retention of $\mathrm{Ca}$. In young growing animals (Table 2), increases in the rate of $\mathrm{Ca}$ absorption resulted in an increased retention of $\mathrm{Ca}$, as shown by the increase in size of the positive balance. However, in older animals where the rate of absorption was 
Vol. 26

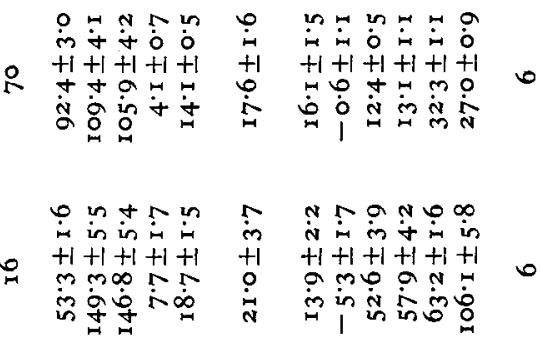

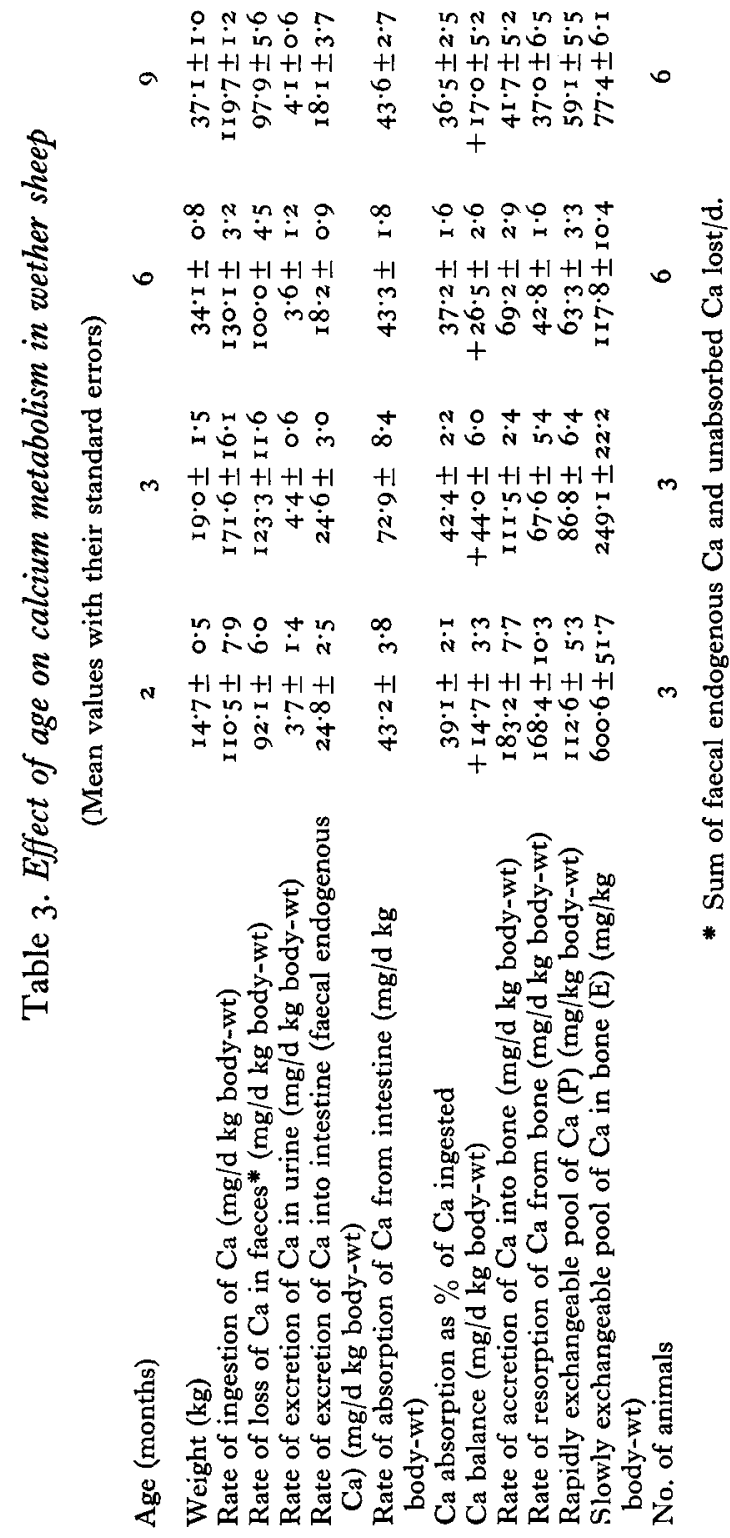


independent of dietary $\mathrm{Ca}$, there was no significant change in the state of $\mathrm{Ca}$ balance and there was virtually no retention. It would appear that it is only in certain circumstances that retention of $\mathrm{Ca}$ can be increased in mature animals. There is considerable evidence that $\mathrm{Ca}$ absorption in adult animals of other species can, under conditions of severe skeletal depletion, be resumed at a rate approaching that observed in infancy (Draper, 1963) and increases in absorption resulting in increased retention have also been reported in ewes in late lactation, after a period of prolonged negative balance during pregnancy and early lactation (Braithwaite et al. 1969, 1970).

Recent work suggests that this increase in the amount of $\mathrm{Ca}$ absorbed by adult animals may be a result of increased active transport of $\mathrm{Ca}$ across the intestine (Schachter, Dowdle \& Schenker, I960; Kimberg, Schachter \& Schenker, 196r). The suggestion of Nicolaysen (1943), however, that $\mathrm{Ca}$ absorption is controlled by an unknown endogenous factor derived from the cellular elements of demineralized bone has not yet been verified.

Fig. I shows that there is a highly significant $(P<0.00 \mathrm{I})$ linear relationship $(r=0.97)$ between the amounts of $\mathrm{Ca}$ absorbed and retained by wether sheep, and the following regression equation was calculated:

$$
V_{a}=2 \mathrm{r} \cdot 8+\mathrm{r} \cdot 076 \Delta,
$$

where $V_{a}$ is the amount of $\mathrm{Ca}$ absorbed (mg/d per $\mathrm{kg}$ body-weight) and $\Delta$ is the balance (mg/d per kg body-weight). This relationship appears to hold for all sheep and is independent of age, sex or breed. In fact, results for pregnant and lactating ewes (Braithwaite et al. 1969, 1970) also obey this equation if the Ca in the foetuses or milk is treated as though it were stored by the mother, and for comparison these values have been included in Fig. $x$. From this regression equation, it can be calculated that an animal must absorb on average $22 \mathrm{mg} \mathrm{Ca} / \mathrm{d}$ per $\mathrm{kg}$ body-weight in order to remain in $\mathrm{Ca}$ balance. If it is unable to do so, either because there is insufficient $\mathrm{Ca}$ available in the diet or because the ability of the intestine to absorb $\mathrm{Ca}$ is limiting, then the animal will move into negative balance. The value of $22 \mathrm{mg} / \mathrm{d}$ per $\mathrm{kg}$ is equal, therefore, to the mean amount of $\mathrm{Ca}$ that must be absorbed to supply the animals' maintenance requirements, i.e. to replace the endogenous losses of $\mathrm{Ca}$ in the urine and faeces.

From this regression equation, it can also be calculated that, for every $\mathrm{mg} \mathrm{Ca}$ absorbed above the mean basal $22 \mathrm{mg} / \mathrm{d}$ per $\mathrm{kg}$ needed for maintenance, approximately $0.93 \mathrm{mg}$ is retained by the animal.

Endogenous loss of $\mathrm{Ca}$. Table 2 shows that an increased dietary intake of $\mathrm{Ca}$ by young growing animals resulted in a slight but significant increase in faecal endogenous loss, whereas increases in the intake of older animals had no appreciable effect. This suggests that faecal endogenous loss may be related to absorption, since the amount of $\mathrm{Ca}$ absorbed also increased in young animals but not in older ones. Furthermore, although the mean dietary $\mathrm{Ca}$ intakes of 2- and 70-month-old animals were almost identical (Table 3), the mean values of faecal endogenous $\mathrm{Ca}$ were quite different $(24.8$ and $\mathrm{I} 4 . \mathrm{I} \mathrm{mg} / \mathrm{d}$ per kg respectively) as also were the rates of absorption (43.2 and I $7.6 \mathrm{mg} / \mathrm{d}$ per $\mathrm{kg}$ ). 
Fig. 2 shows that there is a significant $(P<0.001)$ relationship $(r=0.68)$ between faecal endogenous loss and the rate of $\mathrm{Ca}$ absorption in wether sheep.

The decrease in faecal endogenous loss with age is different from results obtained for cattle, where its value appears to remain remarkably constant throughout life (Hansard et al. 1954; Hansard, Crowder \& Lyke, 1957).

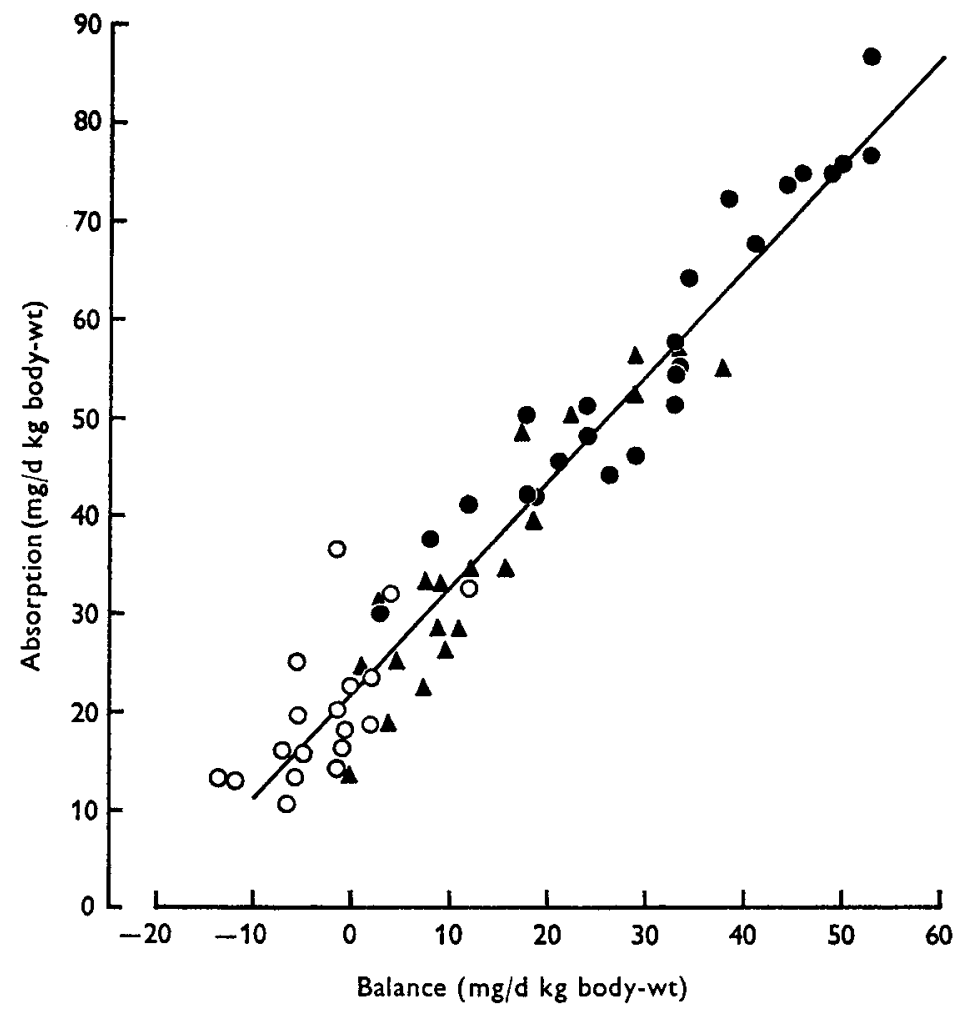

Fig. I. Relationship between calcium balance and the rate of $\mathrm{Ca}$ absorption from the intestine of: - , young growing wethers $(2-9$ months old); $O$, mature wethers (over 9 months old); $\Delta$, pregnant and lactating ewes. $y=2 \mathrm{I} \cdot 80+\mathrm{r} \cdot 08 x . r=0.97$.

Furthermore, values for faecal endogenous $\mathrm{Ca}$ found in the present work are considerably lower than those of $35-40 \mathrm{mg} / \mathrm{d}$ per $\mathrm{kg}$ used by the Agricultural Research Council (1965) for the calculation of dietary requirements of growing sheep (see p. 224), but are similar to the value of $15.2 \mathrm{mg} / \mathrm{d}$ per $\mathrm{kg}$ obtained by them for cattle. The value of $35-40 \mathrm{mg}$ was the mean of results from five groups of workers, and values varied considerably (20-60 mg/d per kg) between the groups. Recently, Field \& Suttle (1969) have estimated that faecal endogenous loss in sheep is I I-22 $\mathrm{mg} / \mathrm{d}$ per $\mathrm{kg}$, and the present results are within this range.

Urinary excretion of $\mathrm{Ca}$ in sheep, although generally low, is considerably higher than in cattle. Its value was approximately $5 \mathrm{mg} / \mathrm{d}$ per $\mathrm{kg}$ in the present work compared with $0.8 \mathrm{mg} / \mathrm{d}$ per $\mathrm{kg}$ for cattle (Agricultural Research Council, 1965). In contrast with the results for faecal endogenous excretion, urinary $\mathrm{Ca}$ losses were not significantly altered either by changes in absorption or by age. 
The total endogenous loss of $\mathrm{Ca}$ (i.e. in urine plus faeces) increased slightly with increased absorption, but varied considerably between animals. The mean value of $25 \mathrm{mg} / \mathrm{d}$ per $\mathrm{kg}$ (range 20-30) is much smaller than the value of $40 \mathrm{mg} / \mathrm{d}$ per $\mathrm{kg}$ used by the Agricultural Research Council (1965) for calculating dietary Ca requirements (see p. 224).

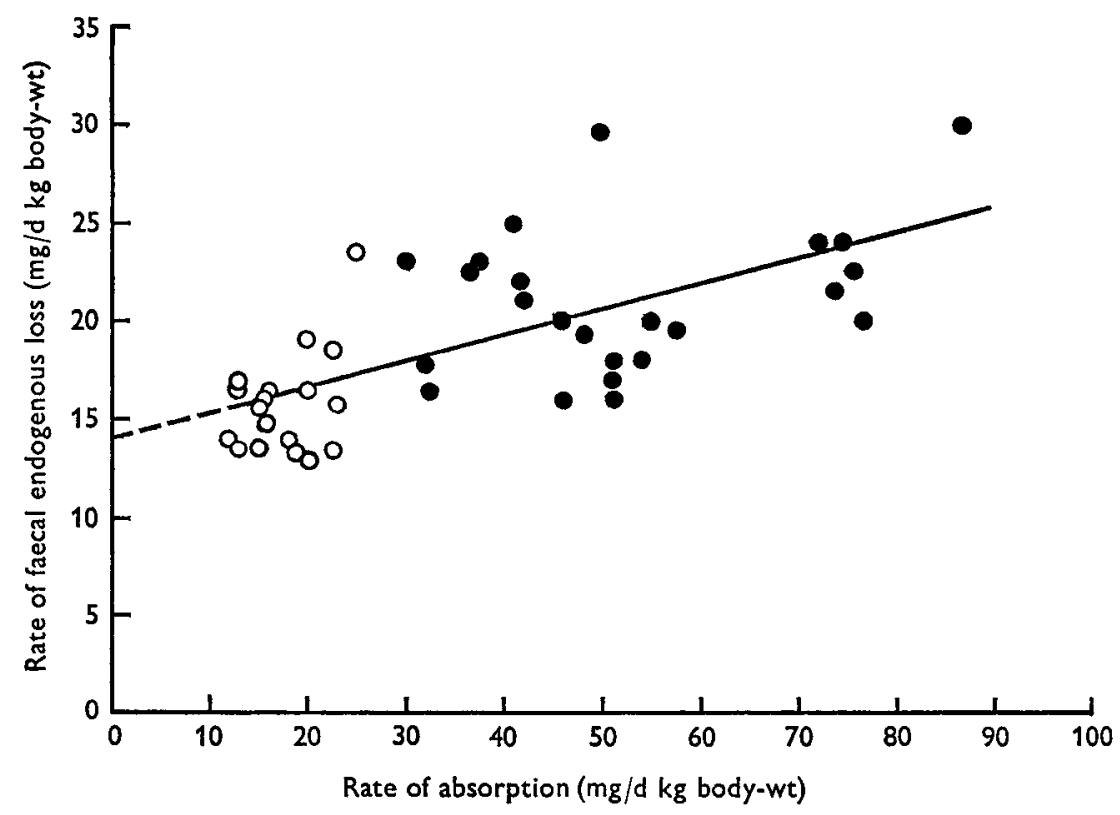

Fig. 2. Relationship between the rate of calcium absorption from the intestine and faecal endogenous loss of $\mathrm{Ca}$ in: 0 , young growing wethers (2-9 months old); $\mathrm{O}$, mature wethers (over 9 months old). $y=I_{4} \cdot 1 \mathrm{I}+0 \cdot 13 x \cdot r=0.68$.

Bone Ca metabolism. There was a significant difference in the rate of resorption of $\mathrm{Ca}$ from bone by the two groups of young growing animals with the different levels of $\mathrm{Ca}$ intake (Table 2). The rate of accretion of $\mathrm{Ca}$ into bone, however, altered only slightly. Ca homoeostasis in these young growing animals, therefore, appears to be controlled mainly by changes in the rate of bone resorption, as it is in lactating ewes (Braithwaite et al. 1969). These observations are consistent with the concept that homoeostasis is regulated by a combination of parathyroid hormone and thyrocalcitonin which control $\mathrm{Ca}$ metabolism by increasing or decreasing, respectively, the rate of bone resorption (Copp, 1969). They are different, however, from those obtained in man (Nordin, MacGregor \& Bluhm, 1963), where changes in Ca retention in normal subjects and subjects with osteoporosis were brought about by changes in the rates of both accretion and resorption.

In mature animals, there was no significant difference at the two levels of intake in the rate of either accretion or resorption (Table 2). This, however, is not surprising, since there were no significant differences in the amounts of $\mathrm{Ca}$ absorbed or retained.

The rapid decrease in the rate of $\mathrm{Ca}$ accretion into bone in the first few months of 
life, followed by the slower decline later in life (Table 3), must be an effect of age, since its value was not altered by changes in dietary $\mathrm{Ca}$ intake. Furthermore, accretion rates have been estimated in the foetus at two stages of gestation (unpublished observations) and were found to remain fairly constant at about $400 \mathrm{mg} / \mathrm{d}$ per $\mathrm{kg}$ foetal bodyweight, a value very much higher than that found in the 2 -month-old animals in the present work.

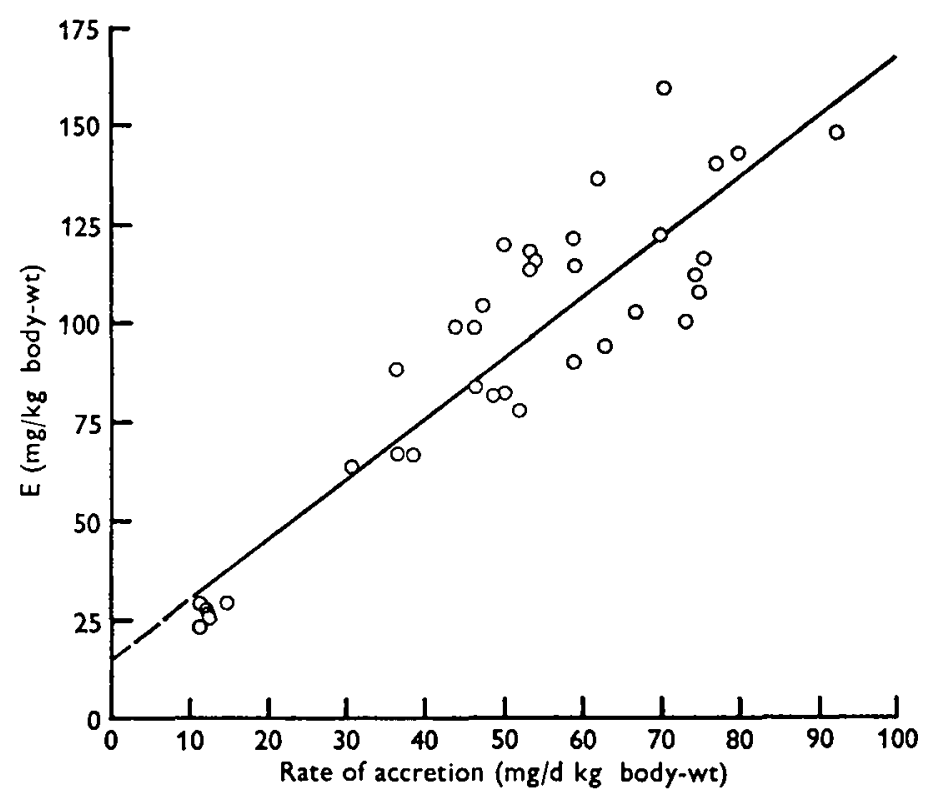

Fig. 3. Relationship betwcen the rate of accretion of calcium into bone and the size of the slowly exchangeable Ca pool (E) of bone for sheep over 3 months of age. $y=15 \cdot 33+1 \cdot 53 x$. $r=0.91$.

Since bone resorption alters considerably in young growing animals with changes in dietary intake, the values of Table 3 are not strictly comparable, but in spite of the variations in intake, it is apparent that this process also decreased rapidly in early life and then more slowly. In mature animals, where net retention of $\mathrm{Ca}$ by bone was almost zero, accretion and resorption rates were very nearly equal and decreased at about the same rate with increasing age.

Exchangeable $\mathrm{Ca}$ pools. Table 2 shows that the rapidly exchangeable $\mathrm{Ca}$ pool (P) and the slowly exchangeable bone pool (E) were not significantly changed in either young growing animals or mature adults by variations in dietary intake. The changes in the sizes of these pools shown in Table 3, therefore, must result from ageing. Both $\mathrm{P}$ and $\mathrm{E}$ decreased rapidly in size in the first few months of life and then more slowly. $\mathrm{E}$, however, decreased to a much greater degree than $\mathrm{P}$.

Fig. 3 shows that there is a significant $(P<0.001)$ relationship $(r=0.91)$ in animals over 3 months of age between the size of $\mathrm{E}$ and the rate of $\mathrm{Ca}$ accretion into bone and, furthermore, preliminary experiments on the effect of hexoestrol on $\mathrm{Ca}$ metabolism show that treatment of wether lambs with this oestrogen results in an 
increase both in the rate of bone accretion and in the size of $\mathrm{E}$ (unpublished observations).

Calculation of the dietary Ca requirements of young sheep gaining weight at different rates. From the small amount of information available on the chemical composition of sheep carcasses, a value of $8.9 \mathrm{~g} \mathrm{Ca}$ was taken by the authors of The Nutrient Requirements of Farm Livestock (Agricultural Research Council, 1965) as corresponding to a gain of $\mathrm{I} \mathrm{kg}$ in body-weight, irrespective of age, weight or breed of sheep. Application of this value to results obtained in the present work gives the amounts of $\mathrm{Ca}$ that would be retained by animals growing at different rates. From the regression equation calculated from the results shown in Fig. I, the amount of $\mathrm{Ca}$ that must be absorbed to

\section{Table 4. Estimated calcium requirements of sheep growing at different rates}

\begin{tabular}{|c|c|c|c|c|c|c|c|c|c|c|}
\hline \multirow{3}{*}{$\begin{array}{c}\text { Body-wt } \\
\text { (kg) }\end{array}$} & \multirow{2}{*}{\multicolumn{2}{|c|}{$\begin{array}{c}\text { Availability } \\
\text { of Ca } \\
(\%)\end{array}$}} & \multicolumn{8}{|c|}{$\begin{array}{l}\text { Ca requirement }(\mathrm{g} / \mathrm{d}) \text { when the sheep is gaining } \\
\text { weight at a rate of: }\end{array}$} \\
\hline & & & \multicolumn{2}{|c|}{$50 \mathrm{~g} / \mathrm{d}$} & \multicolumn{2}{|c|}{$100 \mathrm{~g} / \mathrm{d}$} & \multicolumn{2}{|c|}{$200 \mathrm{~g} / \mathrm{d}$} & \multicolumn{2}{|c|}{$300 \mathrm{~g} / \mathrm{d}$} \\
\hline & $a$ & $b$ & $a$ & $b$ & $a$ & $b$ & $a$ & $b$ & $a$ & $b$ \\
\hline 20 & 40 & 55 & $2 \cdot 3$ & $2 \cdot 3$ & 3.5 & $3^{\cdot I}$ & 5.9 & $4 \cdot 7$ & 8.3 & $6 \cdot 3$ \\
\hline 30 & 40 & $5^{\circ}$ & $2 \cdot 8$ & $3 \cdot 3$ & 4.0 & 4.2 & $6 \cdot 4$ & $6 \cdot 0$ & 8.8 & 7.7 \\
\hline 40 & 35 & 50 & 3.9 & $4 \cdot \mathrm{I}$ & $5 \cdot 2$ & 5.0 & $8.0^{\circ}$ & 6.8 & 10.7 & $8 \cdot 5$ \\
\hline 50 & 35 & 40 & 4.5 & 5.4 & 5.8 & $6 \cdot 4$ & $8 \cdot 6$ & $8 \cdot 4$ & $\mathrm{II}^{\cdot} 3$ & 10.4 \\
\hline 60 & 35 & 40 & $5 \cdot I$ & $6 \cdot 3$ & $6 \cdot 5$ & $7 \cdot 3$ & $9 \cdot 2$ & $9 \cdot 2$ & - & - \\
\hline 70 & 35 & 40 & $5 \cdot 7$ & $7 \cdot 2$ & $7 \cdot 1$ & $8 \cdot 2$ & $9 \cdot 6$ & 10.1 & - & - \\
\hline
\end{tabular}

$a$, present estimates; $b$, estimates of the Agricultural Research Council (I965).

produce a given retention can be determined. Since the percentage absorption of $\mathrm{Ca}$ by young growing sheep fed on a diet of hay and concentrates is independent of the $\mathrm{Ca}$ intake and remains constant at $35-40 \%$ (see Table 3 ), it is possible to use this value to calculate the dietary requirements for $\mathrm{Ca}$ of young sheep gaining weight at different rates.

The values thus obtained are shown in Table 4, together, for the purpose of comparison, with those calculated by the Agricultural Research Council (1965). On the whole, the two sets of values are in good agreement. However, the requirements of small sheep (20-30 kg body-weight) calculated from the present results are greater at the higher rates of gain than those recommended by the ARC, whereas those for larger sheep $(50-70 \mathrm{~kg}$ body-weight) gaining at the lower rates are smaller than the corresponding values of the ARC. These differences result from different values being used by the ARC and the present authors for faecal endogenous $\mathrm{Ca}$ losses $(40 \mathrm{mg} / \mathrm{d}$ per $\mathrm{kg}$ by the ARC compared with $20-30 \mathrm{mg} / \mathrm{d}$ per $\mathrm{kg}$ in the present work) and for efficiency of $\mathrm{Ca}$ absorption (40-55\% by the ARC compared with $35-40 \%$ in the present work).

No requirements have been calculated for growing animals weighing less than $20 \mathrm{~kg}$, because these animals would normally be on a milk diet and it is known that young milk-fed animals can absorb Ca with nearly $100 \%$ efficiency (Lengemann, Comar \& Wasserman, I957). 
The present results show that $\mathrm{Ca}$ retention is not normally increased in mature animals by increases in dietary $\mathrm{Ca}$ intake. In these animals only sufficient $\mathrm{Ca}$ is absorbed to meet the maintenance requirements and animals tend to be in balance. It is possible, however, to calculate the minimum dietary $\mathrm{Ca}$ intake necessary for maintenance in these animals and at the same time it must be pointed out that $\mathrm{Ca}$ intakes above this minimum value are of no further benefit. The mean amount of $\mathrm{Ca}$ that must be absorbed for maintenance is $22 \mathrm{mg} / \mathrm{d}$ per $\mathrm{kg}$ (Fig. $\mathrm{r}$ ) and the maximum efficiency of absorption of $\mathrm{Ca}$ for adult sheep from a hay and concentrate diet is approximately $33 \%$. A $50 \mathrm{~kg}$ sheep, therefore, requires a dietary Ca intake of $3.3 \mathrm{~g} / \mathrm{d}$ for maintenance. This value compares with $4.4 \mathrm{~g} / \mathrm{d}$ calculated by the Agricultural Research Council (1965) and $3.2 \mathrm{~g} / \mathrm{d}$ by the National Research Council (1968).

We thank Dr R. F. Glascock for his advice and encouragement while this work was being performed. We also thank Mr G. Lovering for technical assistance and $\mathrm{Mr} R$. Ellis and Mr A. Wilim for their care of the experimental animals. One of us (Sh. R., a visiting worker from the Pakistan Atomic Energy Commission, Lahore) is the holder of a Colombo Plan Fellowship.

\section{REFERENCES}

Agricultural Research Council (1965). The Nutrient Requirements of Farm Livestock. No. 2 Ruminants. London: H. M. Stationery Office.

Aubert, J.-P. \& Milhaud, G. (1960). Biochim. biophys. Acta 39, 122.

Braithwaite, G. D., Glascock, R. F. \& Riazuddin, Sh. (1969). Br. F. Nutr. 23, 827.

Braithwaite, G. D., Glascock, R. F. \& Riazuddin, Sh. (1970). Br. F. Nutr. 24, 66r.

Bronner, F. (1964). In Mineral Metabolism Vol. 2, Part A, Ch. 2o [C. L. Comar and F. Bronner, editors]. New York and London: Academic Press Inc.

Burkinshaw, L., Marshall, D. H., Oxby, C. B., Spiers, F. W., Nordin, B. E. C. \& Young, M. M. (1969). Nature, Lond. 222, 146.

Copp, D. H. (1969). F. Endocr. 43, 137.

Draper, H. H. (1963). In The Transfer of Calcium and Strontium Across Biological Membranes p. 97 [R. H. Wasserman, editor]. New York and London: Academic Press Inc.

Field, A. C. \& Suttle, N. F. (1969). F. agric. Sci., Camb. 73, 507.

Hansard, S. L., Comar, C. L. \& Plumlee, M. P. (1954). F. Anim. Sci. 13, 25.

Hansard, S. L., Crowder, H. M. \& Lyke, W. A. (1957). F. Anim. Sci. 16, 437.

Kimberg, D. V., Schachter, D. \& Schenker, H. (196r). Am. F. Physiol. 200, 1256.

Lengemann, F. W., Comar, C. L. \& Wasserman, R. H. (1957). $\mathcal{F}$. Nutr. 6r, 57 I.

National Research Council (1968). Publs natn. Res. Coun., Wash. no. 1693.

Neuman, W. F., Terepka, A. R., Canas, F. \& Triffitt, J. T. (1968). Calc. Tissue Res. $2,262$.

Nicolaysen, R. (1943). Acta physiol. scand. 5, 200.

Nordin, B. E. C., MacGregor, J. \& Bluhm, M. M. (1963). Clin. Sci. 24, 301.

Schachter, D., Dowdle, E. B. \& Schenker, H. (1960). Am. F. Physiol. 198, 263.

Visek, W. J., Monroe, R. A., Swanson, E. W. \& Comar, C. L. (1953). Y. Nutr. 50, 23. 